\title{
JONES \% UNITED STATES: TAX TREATMENT OF GIFTS OF STOCK IN A LIQUIDATING CORPORATION
}

In Jones $v$. United States, ${ }^{1}$ the Sixth Circuit Court of Appeals held that a taxpayer's donation of shares of corporate stock to a charity, after the shareholders adopted a plan of complete liquidation, but before any liquidation dividends were paid, constituted an anticipatory assignment of income in light of the "realities and substance" of the situation. Therefore, the liquidation proceeds on the gift stock were to be taxed as income to the donor. ${ }^{2}$ In so holding, the court reversed its previous position ${ }^{3}$ and adopted an approach taken by the Second and Eighth Circuits. ${ }^{4}$

This Comment will examine the general doctrine and previous case law in this area, and will evaluate the impact of Jones. It will conclude that Jones' endorsement of the "realities and substance" test set out by the Second and Eighth Circuits was an unfortunate step, and will propose that future courts adopt instead a per se rule that a gift of corporate stock after a shareholders' vote to liquidate will always result in taxation of the liquidation proceeds to the donor. Such a rule would be consistent with the national income tax policy, and would not, despite its mechanical operation, cause arhitrary results.

\section{BACKGROUND}

The set of income taxation principles grouped under the general label, "assignment of income doctrine," is not a concrete body of law lending itself to clear, capsule treatment. ${ }^{5}$ For pres-

1531 F.2d 1343 (6th Cir. 1976).

${ }^{2}$ Unlike most dividends, a dividend distributed in conncection with a complete corporate liquidation is treated as capital gain to the shareholder, even though the dividend includes previously undistributed profits. See I.R.C. $\$ 331$ (a)(1). If the stockholder transfers the stock to a charity before liquidation, he may be able to deduct the entire value of the stock without being required to pay any capital gains tax. See I.R.C. $\$ 170$. If the court holds the transfer to be an anticipatory assignment of income, the transferor must pay the tax on the capital gains income. If, however, the transfer is characterized as a bona fide transfer of a capital asset, the transferor pays no capital gains tax. See Blair v. Commissioner, 300 U.S. 5 (1937).

${ }^{3}$ Jacobs v. United States, 390 F.2d 877 (6th Cir. 1968), aff'g mem. 280 F. Supp. 437 (S.D. Ohio 1966).

${ }^{4}$ See Hudspeth v. United States, 471 F.2d 275 (8th Cir. 1972); Kinsey v. Commissioner, 477 F.2d 1058 (2d Cir. 1973).

${ }^{5}$ For an excellent general discussion of the doctrine, see Lyon \& Eustice, Assignment of Income: Fruit and Tree as Irrigated by the P.G. Lake Case, 17 TAX L. Rev. 293 (1962). 
ent purposes, however, it will suffice to note that the courts, since the landmark cases of several decades ago, ${ }^{6}$ have held that certain attempts to shift one's tax burden to a taxpayer in a lower bracket (or, as in Jones, to a tax-exempt party) by giving the donee the right to receive future income will not succeed. To defeat such tax-lowering results, the courts simply tax the donor on the realized income, even though he may have surrendered all control over the income before it was realized.

The Jones situation, however, is not so simple. Complicating matters is the possibility that, despite the shareholders' vote to liquidate, liquidation will not go through to completion. So, the taxpayer, by assigning the right to receive the liquidating dividends, is not assigning an existing right to receive future income; rather, he is assigning only the potential right to receive future income. ${ }^{7}$

Before proceeding to a discussion of the implications of this complicating factor and an analysis of its import in the Jones situation, it will be useful to examine the few precedents involving assignments of stock after liquidation votes.

One of the earliest reported cases dealing with the tax consequences of a gift of stock in a liquidating corporation was Howard Cook. ${ }^{8}$ The Tax Court there held the donor taxable on the liquidation proceeds, stressing that prior to the date of the gift (1) most of the corporate assets had been sold, and (2) the shareholders had voted to liquidate completely and dissolve the corporation by a certain date. ${ }^{9}$ The court also emphasized that the taxpayer intended to make gifts of liquidating dividends rather than bona fide gifts of stock. The taxpayer, said the court, "was well aware that the corporate activities had all but ceased except for the actual distribution in liquidation. He knew that the only possible benefits his sons could derive from the gifts

${ }^{6}$ E.g., Helvering v. Horst, 311 U.S. 112 (1940); Lucas v. Earl, 281 U.S. 111 (1930); cases cited in Lyon \& Eustice, supra note 5, at 296-300.

"To illustrate the significance of the term."potential," it may be useful to delineate the boundaries of the assignment of income doctrine. Where there is no doubt that the assigned right to recieve income will be realized, the income will very likely be taxed to the donor. See, e.g., Helvering v. Horst, 311 U.S. 112 (1940) (gift of bond interest coupons). Where, on the other hand, there is considerable doubt that any income will be realized, the court may decide not to tax the donor. See, e.g., Paul A. Teschner, 38 T.C. 1003 (1962) (assignment of right to proceeds in event taxpayer won contest). Although the possibility that the liquidation will not be completed is the controversial factor in the Jones situation, this Comment takes the position that, once the shareholders have voted to liquidate, the donor should be taxed regardless of any uncertainty that the liquidation will be completed. See text accompanying notes 73-75 infra.

${ }^{8} 5$ T.C. 908 (1945).

${ }^{9}$ Id. at 911 . 
would be to receive the amounts distributed in liquidation of those shares."10

Subsequent to Cook, a federal district court held in Apt $v$. $B_{\text {Birmingham }}{ }^{11}$ that liquidation proceeds paid upon certain gift stock constituted income to the donee rather than to the donor. The donor in $A p t$ transferred the stock to his wife only a few days prior to liquidation, but before the shareholders voted to liquidate. At the time of the transfer, he (the sole corporate shareholder) intended to effect the dissolution of the corporation in the immediate future and had already drafted the necessary papers. ${ }^{12}$ The court considered these elements insufficient to constitute a taxable event. ${ }^{13}$ With regard to circumstances that would support a finding that the stock donor was taxable on the liquidation proceeds flowing to the donee, the court said:

It is the contention of the plaintiff [donor] that in a situation such as is presented in this case there can be no severance of the gain from the investment until either the corporation has been formally dissolved or the first legal step toward corporate dissolution has been taken. It would seem that a vote to dissolve a corporation constitutes such a legal step as to effect a severance of the gain from the investment for federal income tax purposes. It is also possible that in a situation where for all practical purposes corporate stock had no further purposes to fullfill except to receive the corporate assets upon dissolution and the actual dissolution was a mere formality, it could be considered that a severance had taken place without a formal vote of dissolution. ${ }^{14}$

In Winton $0 . \mathrm{Kelm}^{15}$ the taxpayer transferred certain shares

${ }^{10} \mathrm{Id}$. This is an early example of the unfortunate tendency on the part of some courts to consider the individual taxpayer's intent in determining the tax consequences of gifts of stock in liquidating corporations. Later instances of this tendency are discussed at text accompanying notes 50-61 infra.

1189 F. Supp. 361 (N.D. Iowa 1950).

${ }^{12} I d$. at 393.

13 "The intent to dissovle a corporation at a future time and the preparation of papers to carry out that intent .. . would not of itself be such a step as to work a severance of the gain from the investment and would not constitute a taxable event for federal income tax purposes." Id.

${ }^{14}$ Id. (citation omitted). On the facts of the case the court held that the gift stock "still had a purpose to serve other than to recieve the corporate assets upon dissolution since the corporation was to actively carry on its operations to the end of the quarterly accounting period. ..."Id.

15 122 F. Supp. 649 (D. Minn.), appeal dismissed, 216 F.2d 957 (8th Cir. 1954). 
of stock to a charitable trust after the corporate directors recommended a liquidation plan, but three days before the shareholders voted to approve it. The district court held for the taxpayer on the ground that "[w]hat had been done looking toward dissolution, such as the action by the Board of Directors providing for such vote by the shareholders and the solicitation of consents, was merely preliminary to substantive action and comparable to preparation of the [dissolution papers] in the $A p t$ case." 16 In reaching its holding, the court made it clear that it regarded shareholder approval of a liquidation plan to constitute such "substantive action" as would fix tax liability for liquidation proceeds upon the person holding the stock at the time of the vote:

[T] ]he basic factor . . . is whether or not there had been a severance of the gain in value of the stock prior to the transfer. If such has occurred it is taxable to the transferor although he thereafter purports to avoid it by assignment of the stock. If it occurs after the transfer it is an incident of stock ownership and taxed to the transferee.

No doubt realization occurs upon the completion of dissolution. Since the substantial element in such dissolution is the stockholders' vote, the formalities following thereafter in order to complete dissolution may be ignored. ${ }^{17}$

As the transfers in question occurred prior to such vote, the court held them effective to shift to the donee the tax liability for the liquidation proceeds. ${ }^{18}$

Thus, up to this point, there were at least two courts that had stated that from the time the corporate shareholders adopted a plan of liquidation, a gift of stock would constitute a transfer of a right to receive liquidation proceeds rather than an interest in a viable corporation. ${ }^{19}$

In Jacobs $v$. United States ${ }^{20}$ the shareholders adopted a plan of liquidation prior to the taxpayer's gift of shares to a family

${ }^{16} I d$. at 653 .

${ }^{17} \mathrm{Id}$.

${ }^{18} I d$.

${ }^{19}$ The $A p t$ and Winton courts clearly were of this view. The Cook court, however, relied partially on the donor's intent, rather than basing its holding solely on the shareholders' adoption of a liquidation plan prior to the gift of stock. See text accompanying notes 9-10 supra.

20280 F. Supp. 437 (S.D. Ohiol 1966), aff'd. mem., 390 F.2d 877 (6th Cir. 1968). 
foundation. ${ }^{21}$ Nevertheless, the district judge, whose opinion was adopted by the Sixth Circuit, held that the taxpayer had made a gift of corporate stock rather than an assignment of a right to liquidation proceeds; the proceeds, therefore, were to be treated as income to the donee rather than to the donor. The judge based his conclusion on the finding that "[i]n spite of the arguments concerning the unlikelihood of a repudiation of the dissolution proceedings prior to their finality, the fact remains that such abandonment was entirely possible." 22

The Jacobs "technically possible abandonment" test ${ }^{23}$ has been adopted by two federal district courts in the Fourth and Fifth Circuits. ${ }^{24}$ In each case the court held that a donor of corporate stock was not to be taxed on liquidation proceeds flow-

${ }^{21} I d$. at 438.

${ }^{22}$ Id. at 439. In distinguishing Jacobs from Friedman v. Commissioner, 346 F.2d 506 (6th Cir. 1965), in which the taxpayer made a donation of insurance policies that had increased in value due to additions of annual interest to the reserves, the court emphasized that the taxpayer in Jacobs did not have an absolute and indefeasible entitlement to the dissolution proceeds. In Friedman, the Sixth Circuit held that the gain realized upon maturity of the policies was taxable to the donor.

${ }^{23}$ For a discussion of the Jacobs test and of the taxation of gifts of stock in a liquidating corporation, see 1974 WASH. U.L.Q. 309.

${ }^{24}$ Simmons v. United States, 341 F. Supp. 947 (M.D. Ga. 1972); Charleston Nat'l Bank v. United States, 323 F. Supp. 530 (S.D.W. Va. 1971). In addition, the Jacobs decision may have been partially relied upon by one circuit court. In Rushing v. Commissioner, 441 F.2d 593 (5th Cir. 1971), the Fifth Circuit held that taxpayers making installment sales of stock in a wholly owned corporation to an independent corporate trustee after shareholder adoption of a liquidation plan were entitled to the benefits of the installment sales provision of the Internal Revenue Code, I.R.C. $\S 453$, and were not to be treated as if they constructively had received the entire sales price dividend in the year of the sale. In so holding, the court affirmed the decision of the Tax Court, W.B. Rushing, 52 T.C. 888 (1969), which had relied in part on Jacobs.

The Tax Court, noting that the tapayers had transferred all of their corporate stock to irrevocable trusts for each of their children, stressed that the liquidation would not have been completed without an "affirmative act" on the part of the trustees in authorizing the liquidation distributions and that, as the only shareholders, the trusts could have voted to rescind the resolution of liquidation. Id. at 897 .

In affirming the Tax Court decision, the Fifth Circuit emphasized that the case did not involve an attempt by the taxpayers to shift the gain to a second taxable entity in order to take advantage of the latter's tax bracket; there would be no effect on the character or total amount of gain eventually realized. As for the trustee, the court stressed only that he was independent; there was no mention of the need for the trustee's "affirmative action" to complete the liquidation or of the fact that the trusts could have singlehandedly voted to rescind the resolution of liquidation.

It thus seems that the Fifth Circuit, in conspicuously ignoring those parts of the Tax Court's opinion that were derived from the latter court's reliance on the technical approach of Jacobs, was not relying on Jacobs. Rather, the court considered as distinguishing the fact that a deferral rather than a shifting of gain was involved. Perceiving the issue to be one of control, the court used its finding that the trustee was independent of taxpayers' control (and the imminent liquidation dividend consequently beyond their reach) to allow the taxpayers the benefit of reporting their gain on the sale of stock as the periodic payments were actually received. 
ing to the donee, even though shareholder adoption of a liquidation plan preceded the gift. ${ }^{25}$ This approach, as established in Jacobs and applied by the district courts, suggests that a transfer of stock during liquidation proceedings is not an anticipatory assignment of income if there is a possibility, no matter how remote, that the plan of liquidation might be abandoned.

The Eighth Circuit, in Hudspeth \%. United States, ${ }^{26}$ rejected the "technically possible abandonment" test of Jacobs, stating that when shareholders have adopted a plan of liquidation and abandonment of that plan is unlikely, "the realities and substance of the events must govern our determination, rather than formalities and remote hypothetical possibilities." ${ }^{27}$ Following Hudspeth, the Second Circuit, in Kinsey v. Commissioner, ${ }^{28}$ adopted the "realities and substance" test, taxing a stock donor on liquidation proceeds when the gift occurred subsequent to shareholder adoption of a liquidation plan. ${ }^{29}$

Thus, when again presented with the situation it had previously confronted in Jacobs, the Sixth Circuit was faced with the rejection of its "technically possible abandonment" test by the only two circuit courts that had dealt with similar situations and the adoption by both courts of a "realities and substance" test.

${ }^{25}$ Simmons v. United States, 341 F. Supp. 947, $951-52$ (M.D. Ga. 1972); Charleston Nat'l Bank v. United States, 323 F. Supp. 530,532 (S.D.W. Va. 1971).

${ }^{26} 471$ F.2d 275 (8th Cir. 1972), rev'g 335 F. Supp. 1401 (E.D. Mo. 1971).

${ }^{27} \mathrm{Id}$. at 277 . In Hudspeth, as in Jacobs, the taxpayer made a gift of stock subsequent to shareholder approval of a liquidation plan but prior to the first distributions of the proceeds. The district court, relying in part on Jacobs, found the issue to be whether the taxpayer was "absolutely and indefeasibly entitled in the immediate future to the liquidating distributions on the stock donated by him." Hudspeth v. United States, 335 F. Supp. 1401, 1404 (E.D. Mo. 1971), rev'd 471 F.2d 275 ; 8 th Cir. 1972). The district court construed Mo. Rev. STAT. $\$ \$ 351.465, .470$ (1969) to permit rescission of the liquidation plan prior to filing dissolution plans with the state, and held that the taxpayer was not to be taxed on the gain attributable to the donated shares. $335 \mathrm{~F}$. Supp. at $1404-05$.

The Eighth Circuit reversed on two alternative grounds. First, the court construed the Missouri statute to make the plan of complete liquidation irreversible upon adoption, so that even under the district court's approach the taxpayer would be taxable. But the court went on to reject the district court's "technically possible abandonment" approach in favor of a "realities and substance" approach under which the taxpayer was also found to be liable for the tax. $471 \mathrm{~F} .2 \mathrm{~d}$ at 277.

${ }^{28} 477$ F.2d 1058 (2d Cir. 1973).

${ }^{29} \mathrm{Id}$. at 1063 . Reviewing the facts in light of the "realities and substance" test, the court identified three reasons why it was unlikely that the plan of liquidation would be abandoned: (1) a plan of liquidation under I.R.C. $\$ 337$ had been adopted, and that section requires liquidation within one year of the adoption of the plan in order for the corporation to avoid a taxable gain on the sale of assets, see note 32 infra; (2) the donee, although holding a majority of the stock, did not have the requisite two-thirds control to prevent the liquidation unilaterally; and (3) the donee's policy was to liquidate shares of stock given to it. The court concluded that the transfer of the stock was an anticipatory assignment of the liquidation proceeds. 


\section{JoNeS V. UNITED STATES AND THE "Realities and Substance” Test}

The issue in Jones was whether the gift of shares of corporate stock to a charity, after the shareholders had adopted a plan of complete liquidation, constituted an anticipatory assignment of income that warranted treating the liquidation proceeds as income taxable to the donor. Correctly applying the Jacobs rationale, the district court held for the donor, reasoning that because the shareholders could have abandoned liquidation proceedings after the gift was made, the gift should be viewed as a bona fide transfer of stock. ${ }^{30}$

On appeal, the Sixth Circuit summarized the rejection of its Jacobs test by the Hudspeth and Kinsey courts and then stated that "[u]pon consideration, we are persuaded to adopt the rule expressed by the Second and Eighth Circuits that the 'realities and substance' of the events and not hypothetical possibilities should govern our determination whether an anticipatory assignment of income has occurred." 31 Under the "realities and substance" test, the court found that completion of the liquidation proceedings was a "practical certainty," as indicated by three circumstances: (1) the taxpayer expected the liquidation proceedings to be completed, as explicitly demonstrated by a letter to one of the donees stating that the corporation was being liquidated and that he would be notified when to present the stock for cash redemption; (2) the liquidation was conducted in accordance with section 337 of the Internal Revenue Code of 1954, which conditions the nonrecognition of gain on the sale of assets upon liquidation within one year of the adoption of a liquidation plan; ${ }^{32}$ and (3) the shareholders voted overwhelmingly $(968,605$ to 175$)$ to approve the liquidation plan. On the basis of its findings, the court held that the taxpayer had anticipatorily assigned liquidation proceeds to the donees. ${ }^{33}$

${ }^{30}$ Jones v. United States, Civ. No. 73-220 (S.D. Ohio, filed Feb. 19, 1975), rev'd, 531 F.2d 1343 (6th Cir. 1976).

31531 F.2d at 1345.

32 I.R.C. $\$ 337$ (a) provides:

(a) General rule.-If-

(1) a corporation adopts a plan of complete liquidation on or after June 22, 1954, and

(2) within the 12-month period beginning on the date of adoption of such plan, all of the assets of the corporation are distributed in complete liquidation, less assets retained to meet claims, then no gain or loss shall be recognized to such corporation from the sale or exchange by it of property within such 12-month period.

Loss of this exemption would have subjected the corporation to taxation on the gain on all assets that were sold.

${ }^{33} 531$ F.2d at 1345. 
The dissent in Jones argued that even under the "realities and substance" test, Hudspeth and Kinsey were distinguishable from Jones. ${ }^{34}$ Because the dissent found it "difficult to imagine a case with facts more favorable to the claim of a taxpayer than the present one,"35 it concluded that the majority in effect had adopted "a per se rule that a gift of stock of a corporation in the process of liquidation will always be treated as an anticipatory assignment of income." 36

Although the dissent did not specify what it meant by the phrase "in the process of liquidation," an examination of its language suggests that a corporation is "in the process of liquidation" after the shareholders have adopted a plan of liquidation. ${ }^{37}$ In a discussion comparing the facts of Hudspeth, Kinsey and Jones, the Jones dissent in each instance regarded the adoption of the liquidation plan as no more than a starting point in the liquidation process, viewing subsequent events (the pre-gift distribution of liquidation proceeds in Kinsey) or extrinsic elements (the retention of corporate control by the donor in Hudspeth) as the critical elements on which a finding of tax liability should be based. ${ }^{38}$ Accordingly, the dissent came to the conclusion that the court should not adopt a per se rule treating gifts of stock of a corporation "in the process of liquidation" as anticipatory assignments of income taxable to the donor. ${ }^{39}$

The question, then, is whether the Jones majority did, in fact, adopt a per se rule that a gift of stock subsequent to shareholder adoption of a plan of liquidation will always be treated as an anticipatory assignment of income.

${ }^{34}$ Id. at 1347 (Lively, J., dissenting). The dissent distinguished Hudspeth on the ground that the taxpayer in that case retained control of the corporation after the gift of the stock, while in Jones the taxpayer never owned more than $10 \%$ of the outstanding stock. The dissent concluded that "[ $t]$ he total domination of a closely held corporation by the donor taxpayer who had committed himself to a plan of liquidation presented to the Hudspeth court a case with 'realities and substance' that are not present in this case." Id.

Kinsey was distinguished on the ground that a major portion of the assets in that case had been distributed in liquidation prior to the date of the gift, whereas in Jones there were no distributions until three months after the gifts were made. The dissent argued that, as a practical matter, the distribution in Kinsey made the decision to liquidate irreversible, because the "donor taxpayer . . . would have suffered adverse tax consequences if the plan of liquidation had been abandoned because the distribution he had already received when he made the gifts of stock would be taxed as ordinary income" rather than as capital gain. Id.

${ }^{35} \mathrm{Id}$.

${ }^{36} I d$.

${ }^{37}$ This inference follows from the fact that the only element of the liquidation process that was working against the taxpayer in Jones was the adopting of a plan to liquidate.

${ }^{38} 531$ F.2d at 1346-47 (Lively, J., dissenting).

${ }^{39} \mathrm{Id}$. at 1347. 
It appears that the majority did not adopt such a rule. In criticizing the outcome of the case, the Jones dissent emphasized the facts that favored the taxpayer. The dissent especially noted that the donor in Hudspeth owned a majority of shares in the corporation both before and after the gift of stock to the donee and could thus enforce his decision to liquidate, whereas the donor in Jones retained no such control. And unlike the situation in Kinsey, where liquidation proceeds were distributed before the gift of stock, in Jones no such distribution in liquidation occurred until three months after Mrs. Jones' charitable gift was made. ${ }^{40}$ However, the Jones dissent failed to recognize that the majority's application of the "realities and substance test" for anticipatory assignment of income cases considered not only the weight to be given to the mere adoption of a liquidation plan but also the conclusiveness of the vote to liquidate and the "pressure" exerted by section 337 of the Internal Revenue Code to complete within one year the sale of assets and the distribution of proceeds in order to avoid tax liability on those proceeds. ${ }^{41}$

Contrary to the claim of the dissent, therefore, it is not difficult to conceive of cases with facts more favorable to the taxpayer than those in Jones. Where there has been no sale of corporate assets prior to the date of the gift, for example, there would be a more realistic chance that the corporation might later reverse its decision to liquidate, as the pressure to comply with section 337 to qualify for nonrecognition of gain does not arise until some assets have been sold. ${ }^{42}$ Or the shareholder vote to liquidate, "overwhelming" in Jones, might be a close one, thus leaving open the possibility of reversal if a few shareholders were to change their votes. In both of those hypothetical situations, a court using the rule of the Jones majority might hold for the taxpayer notwithstanding the fact that a shareholder liquidation vote preceded the gift.

${ }^{40} \mathrm{Id}$. at 1346-47. The Jones dissent also listed the following facts as favorable to the taxpayer's claim: (1) the taxpayer had made other gifts of the corporation's stock in years prior to the liquidation (the inference being that the gifts in dispute did not result from a "one shot" tax avoidance scheme to take advantage of the liquidation); (2) the taxpayer testified that she believed that the gifts of stock she made after the adoption of the liquidation plan were no different for tax purposes than those made before; (3) the charitable donees were actual stockholders after the gifts were made, receiving notices of meetings and voting by proxy on issues which arose before the final dissolution of the corporation; and, (4) the gifts did not consist of stock in a closely held corporation (although the taxpayer's husband was president and the owner of $19 \%$ of the outstanding stock, none of the gift stock had come to the taxpayer from her husband). Id. at 1347 .

${ }^{11}$ See text accompanying notes $32-33$ supra.

${ }^{42}$ See note 32 supra. 
It appears, then, that the Jones court did not adopt a per se rule to deal with gifts of stock in liquidating corporations. The question remains, however, whether such a rule should be adopted. Both precedent and policy considerations suggest that it should.

\section{The Proposed Per Se Rule}

In adopting its "technically possible abandonment" test in Jacobs $\%$. United States, ${ }^{43}$ the Sixth Circuit ignored the earlier decisions in Howard Cook, ${ }^{44}$ Apt v. Birmingham, ${ }^{45}$ and Winton v. Kelm, ${ }^{46}$ all of which stated that shareholder approval of a liquidation plan was a crucial event in determining to whom liquidation proceeds of gift stock should be allocated for federal income tax purposes. ${ }^{47}$ Those cases were not ignored, however, by the Eighth Circuit in Hudspeth $v$. United States. ${ }^{48}$ That court concluded:

Thus, Kelm, like Cook and $A p t$, found the shareholders' affirmative vote to liquidate the corporation to be the requisite legal step necessary to effect a "realization" or severance of the gain from the investment such that a subsequent transfer of the stock would constitute a transfer of the liquidation proceeds rather than an interest in a viable corporation. ${ }^{49}$

The Eighth Circuit, however, went on to say in Hudspeth that a new dimension was added by Rushing $v$. Commissioner. ${ }^{50}$ Rushing dealt with an installment sale of stock in a wholly owned corporation after shareholder adoption of a liquidation plan. ${ }^{51}$ Finding that in Rushing "the shareholders' vote was not found to be sufficient to constitute a realization . . .,"52 the Hudspeth court interpreted the case as "delineat[ing] an important exception to

\$3 390 F.2d 877 (6th Cir. 1968); see text accompanying notes 20-25 supra.

44 5 T.C. 908 (1945).

4589 F. Supp. 361 (N.D. Iowa 1950).

46 122 F. Supp. 649 (D. Minn. 1954).

${ }^{47}$ See text accompanying notes 8-18 supra.

4841 F.2d 275 (8th Cir. 1972).

${ }^{49} I d$. at 278 .

so 441 F.2d 593 (5th Cir. 1971).

s1 For a discussion of Rushing, see note 24 supra.

$32471 \mathrm{~F} .2 \mathrm{~d}$ at 278 . As indicated at note 24 supra, however, the Rushing court did not reach the issue of anticipatory assignment of income; rather, the Fifth Circuit relied on the fact that the taxpayer did not assign liquidation proceeds, but merely arranged through a sale transaction to receive them on a deferral basis. The court held that assignment of income principles did not apply to such income deferral. $441 \mathrm{~F} .2 \mathrm{~d}$ at 597-98. 
... [Cook, Apt, and $\mathrm{Kelm}]$ and bring[ing] out the essential factors underlying the basis of the difference - intent' and 'control." "s3

In the situation before it, ${ }^{54}$ the Hudspeth court found that evidence of the taxpayer's "intent to liquidate" was provided by the shareholder vote to liquidate and was reinforced by the sale of corporate assets. The court, however, stated that other "evidence to the contrary could rebut the presumption that the taxpayer was, in fact, liquidating his corporation." 55 The court concluded that " $[t]$ he liquidation had proceeded to such a point where we may infer that it was patently never taxpayer's intention that his donees should exercise any ownership in a viable corporation, but merely that they should participate in the proceeds of the liquidation."56

With regard to the element of "control," the Hudspeth court considered whether the donor or the donee had control of the corporation after the gift of stock. If the donee has received enough shares to exercise control, then he should be taxed on the liquidation proceeds because he would have been able to supersede the donor's initial intent by rescinding the liquidation had he chosen to do so. On the other hand, if the donor has retained control, so that the donee has not received the power to vitiate the donor's intent to liquidate, then "the shareholder's vote remains sufficient to constitute the necessary severance of gain," 57 and the donor should be taxed.

In adopting the Hudspeth court's "realities and substance" test, with its emphasis on "intent" and "control," the Second Circuit in Kinsey ${ }^{58}$ and the Sixth Gircuit in Jones also considered elements other than the mere fact of a shareholder liquidation vote in deciding whether anticipatory assignments of income had occurred. The Kinsey court, analyzing the facts under the "realities and substance" approach, noted that "the completion of the liquidation was in accord both with ... [ [the donee's policy of liquidating any stock given to it] and with the obvious intention of [the donor]." 59 In Jones, the court concluded:

The realities and substance of the events in this case indicate that the taxpayer expected the liquidation pro-

\footnotetext{
${ }^{53} 471$ F.2d at 278.

${ }^{34}$ See note 27 supra.

55471 F.2d at 279.

${ }^{36} I d$. (emphasis supplied).

57 Id.

${ }^{58}$ See notes 28 \& 29 supra \& accompanying text.

${ }^{59} 477$ F.2d at 1063.
} 
ceedings to be completed. In fact, the taxpayer explained in a letter to ... [a donee] that the company was being liquidated and that he would be notified by a bank officer when to present the stock for cash redemption. ${ }^{60}$

The Jones court, in making its finding regarding the taxpayer's expectation of liquidation, seemed concerned not with the fact that such an intent on the part of the donor would prevent her from voting to reverse the plan to liquidate (she had less than one-sixth of the stock necessary to effect such a reversal), but with a theory that considers the donor's intentions with regard to the future of the stock (even if the donor lacks the voting power to enforce the intention) in deciding whether the donor should be taxed. On the basis of this approach the court could conceivably reach different results for two taxpayers who differed only in that one expected liquidation proceedings to be completed while the other expected them to be terminated. The possibility of reaching different results on so tenuous and subjective a ground illustrates the weakness of the "realities and substance" test. Thus, the Hudspeth, Kinsey, and Jones courts have transformed a simple, effective approach based on the relative timing of the liquidation vote and the gift of stock into an indeterminate approach based on the elements of "intent" and "control." 61

Although it might be argued that the "realities and substance" test allows a court to react to the practicalities of a situation rather than mandating a mechanical application of law to facts, it is difficult to conceive of situations in which that approach would further the policy underlying the federal income tax laws. As the United States Supreme Court stated in the landmark case of Helvering $v$. Horst, ${ }^{62}$ "[t] he dominant purpose of the revenue laws is the taxation of income to those who earn or otherwise create the right to receive it and enjoy the benefit of

60531 F.2d at 1345 (emphasis supplied).

61 The "realities and substance" test as developed by these three courts was recently adopted by the Tax Court in Horace E. Allen, 66 T.C. 340 (1976). In taxing the donors on liquidation proceeds paid to their donees, the court emphasized that the shareholders had not only adopted a plan of liquidation, but had also declared the liquidating dividends. Id. at 347. The court ignored the element of intent and considered the element of "control" to be only one of many considerations under the realities and substance test, thereby adding to the indefiniteness of the test. It is unclear how the court would have approached the case had there been only an adoption of the liquidation plan prior to the gift of stock.

62311 U.S. 112 (1940). 
it when paid." 63 Given this maxim of our tax law, the crucial income taxation consideration when a taxpayer makes a gift of stock in a liquidating corporation is not what the donor "intends" to happen with regard to the completion of liquidation, but whether the liquidating process has advanced to the stage where the subsequently distributed liquidation proceeds can be said to have been "earned" 64 before the gift was made. As two courts have stated, these liquidation proceeds are, in effect, "earned" at the time the shareholders of a corporation vote to liquidate, since such a vote supplies the "substantial element" in the liquidation process. ${ }^{65}$ Before that vote, the corporation has not yet entered into the "process of liquidation"; after it, only formalities remain in the path of complete liquidation. ${ }^{66}$

"Intent" is no more relevant when a taxpayer makes a gift of stock in a liquidating corporation than it is when a taxpayer makes a gift of interest coupons torn from his bond, ${ }^{67}$ makes a donation of soon-to-mature insurance policies, ${ }^{68}$ or assigns his right to renewal commissions on certain insurance policies. ${ }^{69}$ In

${ }^{63} I d$. at 119. This underlying principle of the federal income tax system is at the heart of the courts' reluctance to allow assignments of income to succeed as taxlowering devices: "[T] he purpose of the statute to tax the income to him who earns, or creates and enjoys it [cannot] be escaped by "anticipatory arrangements however skilfully devised' to prevent the income from vesting even for a second in the donor." $I d$. at 120 (quoting Lucas v. Earl, 281 U.S. 111,115 (1930)).

64 The word "earned" is used here in a special sense, to describe a concept that is important for the assignment of income doctrine. For this purpose, income is said to be "earned" if its realization has become sufficiently proximate in time, or in likelihood, that the donor of the right to receive it cannot escape taxation. The word is not meant to imply "earning" in the sense of "earning" wages. See, e.g., Eustice, Contract Rights, Capital Gain, and Assignment of Income-the Ferrer Case, 20 TAx L. REv. 1, 44 (1964). ("[A] hope or expectation that income ultimately might be realized . . . is not a sufficient 'earning' of that income by the assignor to hold him liable for the tax when such right eventually materializes in the hands of the transferee.").

${ }^{65}$ See Winton v. Kelm, 122 F. Supp. 649, 653 (D. Minn.), appeal dismissed, 216 F.2d 957 (8th Cir. 1954); Apt. v. Birmingham, 89 F. Supp. 361,393 (N.D. Iowa 1950).

${ }^{66}$ Winton v. Kelm, 122 F. Supp. 649, 653 (D. Minn.), appeal dismissed, 216 F.2d 957 (8th Cir. 1954); John B. Kinsey, 58 T.C. 259, 266 (1972), aff'd, Kinsey v. Commissioner, 477 F.2d 1058 (2d Cir. 1973); cf. Apt. v. Birmingham, 89 F. Supp. 361 , 393 (N.D. Iowa 1950) (no formal vote of liquidation needed where stock has no further practical purpose except to receive the corporate assets upon dissolution).

${ }^{67}$ Helvering v. Horst, 311 U.S. 112 (1940). In holding the donor taxable on the interest paid to the donee, the Court emphasized that the person who creates the right to receive income should be the person taxed on that income. $I d$. at 119 . See text accompanying notes 62-66 supra.

${ }^{68}$ Friedman v. Commissioner, 346 F.2d 506 (6th Cir. 1965). The court, in holding the taxpayer taxable on the maturity payments, stated that one vested with the right to receive income does not escape taxation by assigning away that right. Id. at 508 .

${ }^{69}$ Helvering v. Eubank, 311 U.S. 122, 125 (1940) ("For the reasons stated . . . in the Horst case, we hold that the commissions were taxable as income of the assignor."). 
each of these situations, the courts have held the donor taxable on the proceeds, not because of his intent, but because he performed the necessary acts (or owned the property while the necessary acts were performed) to give to the donee the right to receive the forthcoming income; the donee in each case needed to do nothing more than collect the money.

One might attack the per se rule on the ground that, as was held in Jacobs, there is always a "hypothetical possibility" that a corporation may reverse its decision to liquidate. ${ }^{70}$ Even the Hudspeth, Kinsey, and Jones courts recognized this argument as one of form over substance, ${ }^{71}$ however, and it ignores the Horst axiom that the "purpose of the revenue laws is the taxation of income to those who ... create the right to receive it ...."72

More forcefully, one might argue that the per se rule is inferior to the "realities and substance" test when circumstances indicate a substantial chance that the liquidation will not proceed to completion. For example, suppose that, in a state where a simple majority can initiate or terminate the liquidation process, fifty-one of one hundred shareholders holding an equal number of shares vote to liquidate. If the taxpayer then donates shares of stock to a charity, it undeniably is possible that the liquidation may never be effected. Regardless of how likely it is that the process will be reversed, however, the critical question is whether that likelihood is relevant to determining the tax consequences of the gift. There are several reasons why it is not.

Firstly, for the per se rule to take effect, there must have been a shareholder vote in favor of liquidation. Therefore, at the moment that the rule comes into play, it is likely that the liquidation will take place. This situation, therefore, is not like those cases in which the existence of future income has been held to be too "contingent" to allow the application of the assignment of income doctrine. ${ }^{73}$ In the Jones situation, liquidation will always be an event that is likely, rather than unlikely, to occur. Because the per se rule is not triggered until a shareholder vote to liquidate has occurred-at which time the momentum is in favor of liquidation-the corporation is, at least at that time, under the control of those shareholders who favor liquidation.

Secondly, Professor Eustice has argued that the factor of contingency of the income

\footnotetext{
${ }^{70}$ See text accompanying notes 21-22 supra.

${ }^{71}$ See text accompanying notes 26-31 supra.

72 See note 63 supra \& accompanying text.

${ }^{73}$ See, e.g., Paul A. Teschner, 38 T.C. 1003 (1962); note 7 supra.
} 
is irrelevant in determining the choice of the proper taxpayer, particularly when one examines the facts in the landmark assignment of income decisions in Earl and Eubank. In Earl the taxpayer assigned the right to compensation from services to be rendered in the future, while in Eubank the taxpayer assigned the right to future contingent renewal commissions on insurance policies previously sold by the taxpayer. In neither case did the court give any weight to the speculative or contingent nature of the income. The element of contingency or uncertainty does bear on the proper time for reporting the income as a matter of tax accounting, but such fact should not be allowed to obscure or control the fundamentally different questions of whom [sic] is the proper person to pay the tax on such income when it does eventually become reportable. ${ }^{74}$

Although Eustice notes that "most lower courts have considered this fact [the contingency of the income] to be of great weight,"75 it is theoretically sound to ignore it in the Jones situation. For one thing, as was stated above, the uncertainty usually will be small in such a case. More persuasively, what uncertainty there is adds nothing to the taxpayer's justification for escaping the operation of the assignment of income doctrine. When he makes the gift, he knows that the shareholders have voted to liquidate. At that point it would be difficult for him to argue that his intent was to make a gift of stock in a viable corporation. If such were his actual intention, it would not seem too harsh a rule to require that he make the gift at a time other than when it is evident that, if no action is taken to prevent it, liquidation will take place. Once the per se rule becomes established, taxpayers could, with some certainty, escape a harsh result simply by making gifts of stock before a shareholder vote to liquidate. The rule would afford taxpayers clear notice of its operation, thereby increasing predictability in tax planning.

Finally, when liquidation is, in fact, halted before completion, the donor will not suffer: there will be no liquidation proceeds that can be taxed to him. Of course, a taxpayer, thinking an ongoing liquidation process would be halted, might make a gift of stock with the actual intent of giving shares in a viable corporation. If, much to his surprise, liquidation then went

${ }^{74}$ Eustice, Contract Rights, Capital Gain and Assignment of Income-the Ferrer Case, 20 TAx L. Rev. 1, 43 (1964) (footnote omitted).

${ }^{75}$ Id. 
through to completion, he would be taxed on the proceeds. The taxpayer, however, assumed this risk by making the gift after the "danger point" when the shareholder vote had indicated that the momentum was in favor of liquidation. The per se rule's advantages of clarity, simplicity, and predictability are too great to be outweighed by the possibility that such an unlikely fact situation might arise. The dangers to a prudent taxpayer in such a situation are too slight to warrant the use of the less predictable "realities and substance" approach, at least as that test has been applied by the courts to date.

\section{Conclusion}

The Sixth Circuit's decision in Jones $v$. United States ${ }^{76}$ correctly rejected that circuit's "technically possible abandonment" test as the means for choosing the taxable person in the case of a gift of stock in a liquidating corporation. However, the court should not have adopted the "realities and substance" test of the Second ${ }^{77}$ and Eighth ${ }^{78}$ Circuits. A better test for selecting the taxable person in such a situation is a per se rule that taxes the proceeds of shares of stock in a liquidating corporation to any donor making a gift of such shares after a shareholder vote to liquidate. Such a rule, in addition to being consistent with the federal income tax policy, has the virtues of predictability and fairness to taxpayers.

${ }^{76} 531$ F.2d 1343 (6th Cir. 1976).

${ }^{77}$ Kinsey v. Commissioner, 477 F.2d 1058 (2d Cir. 1973).

${ }^{78}$ Hudspeth v. United States, 471 F.2d 275 (8th Cir. 1972). 
